\title{
Analisis Kualitatif dan Kuantitatif Metabolit Sekunder Ekstrak Etanol Buah Okra (Abelmoschus esculentus L. Moench) dengan Metode Spektrofotometri UV-Vis
}

\section{[Qualitative and Quantitative Analysis of Secondary Metabolites in Ethanol Extract of Okra (Abelmoschus esculentus L. Moench) Fruit with UV-Vis Spectrophotometry Method]}

\author{
Joni Tandi ${ }^{{ }^{*}}$, Bella Melinda ${ }^{1}$, Anita Purwantari ${ }^{1}$, Agustinus Widodo $^{2}$ \\ 1) Program Studi S1 Farmasi, STIFA Pelita Mas Palu \\ 2) Program Studi S1 Farmasi, Fakultas MIPA Universitas Tadulako \\ *)Coresponding author: jonitandi757@yahoo.com
}

\begin{abstract}
This study aims to determine the content of secondary metabolites and the levels of total secondary metabolites in ethanol extract of Okra (Abelmoschus esculentus L. Moench) fruit with UV-Vis Spectrophotometry method. Okra fruit extract was prepared by maceration method with $96 \%$ ethanol. The extract was concentrated using a rotary evaporator that followed by a qualitative test for alkaloids, flavonoids, saponins, and tannins using suitable reagents with the test parameters, while for the qualitative assay using a UV-Vis Spectrophotometry. Qualitative analysis of alkaloids using test parameters of total alkaloids equivalent to quinine, flavonoid using parameter of total flavonoids equivalent to quercetin, saponin using parameters of standard saponins total from the Quillaja Bark, and tannin using test parameters of total tannins equivalent to tannic acid. Qualitative test results indicated that the ethanol extract of Okra fruit tested positive for alkaloids content wich characterized by the orange deposition, flavonoids characterized by the formation of an orange-yellow color, a stable foam for saponins and tannins marked in black. The quantitative analysis resulted alkaloids of $2228.06 \mathrm{mg} / \mathrm{gram}$, flavonoids of $2.79 \mathrm{mg} / \mathrm{gram}$, saponins of $10.03 \mathrm{mg} / \mathrm{gram}$, and tannins of $1973.27 \mathrm{mg} / \mathrm{gram}$.
\end{abstract}

Keywords: Okra fruit, secondary metabolites, UV-Vis spectrophotometry, qualitative, quantitative.

ABSTRAK. Penelitian ini bertujuan untuk mengetahui kandungan metabolit sekunder dan menentukan kadar total metabolit sekunder pada ekstrak etanol buah Okra (Abelmoschus esculentus L. Moench) dengan metode spektrofotometri UV-Vis . Ekstraksi buah Okra menggunakan metode maserasi dengan pelarut etanol $96 \%$ untuk mendapatkan filtrat. Filtrat yang diperoleh dipekatkan menggunakan rotari evaporator dan dilakukan uji kualitatif, meliputi uji alkaloid, flavonoid, saponin dan tanin menggunakan pereaksi yang sesuai dengan parameter uji, sedangkan untuk uji kuantitatif menggunaklan metode spektrovotometri UV-Vis. Analsis kualitatif alkaloid menggunakan parameter uji total alkaloid ekuivalen kuinin, flavonoid menggunakan parameter uji total flavonoid ekuivalen kuersetin, saponin menggunakan parameter uji total saponin standar dari Quillaja Bark, dan tanin menggunakan parameter uji total tanin ekuivalen asam tanat. Hasil uji kualitatif menunjukkan bahwa ekstrak etanol buah Okra positif mengandung alkaloid ditandai dengan adanya endapan jingga, flavonoid ditandai dengan terbentuknya warna kuning jingga, saponin ditandai dengan adanya busa yang stabil, dan tanin ditandai dengan adanya warna hitam. Analisis kuantitatif menghasilkan alkaloid 2228,06 mg/gr, flavonoid 2,79 mg/gr, saponin 10,03 mg/gr, dan tanin 1973,27 mg/gr.

Kata Kunci : Buah Okra, metabolit sekunder, spektrofotometri UV-Vis, kualitatif, kuantitatif.

Riwayat artikel: Diterima 30 Maret 2020, Disetujui 14 April 2020

Cara sitasi: Tandi, J., Melinda, B., Purwantari, A., Widodo, A. (2020). Analisis Kualitatif dan Kuantitatif Metabolit Sekunder Ekstrak Etanol Buah Okra (Abelmoschus esculentus L. Moench) dengan Metode Spektrofotometri UV-Vis. KOVALEN: Jurnal Riset Kimia, 6(1): 74-80.

DOI: https://doi.org/10.22487/kovalen.2020.v6.i1.15044 


\section{LATAR BELAKANG}

Indonesia merupakan salah satu negara yang telah dikenal mempunyai keanekaragaman hayati tinggi. Keberadaan hutan yang luas dan iklim tropis yang mendukung menjadi salah satu pemicu tumbuhnya berbagai macam flora di Indonesia. Dari sekian banyak flora yang tumbuh di Indonesia tersebut, ribuan diantaranya telah dikenal oleh masyarakat Indonesia berkhasiat sebagai obat dan digunakan untuk mengobati banyak penyakit. Sejak lebih dari puluhan tahun yang lalu, masyarakat dunia, tidak saja di negara-negara timur melainkan juga di negara-negara barat, mulai menoleh kembali dan tertarik untuk menggunakan obat-obat alam, yang kita kenal sebagai gerakan kembali ke alam atau Back to Nature (Tandi, 2018). Salah satu tanaman yang memiliki manfaat sebagai obat-obatan adalah buah Okra.

Buah Okra (Abelmoschus esculentus L. Moench) memiliki banyak manfaat, hal ini kemungkinan karena Okra mengandung komponen metabolit sekunder seperti alkaloid terpenoid, flavonoid dan lain-lain. Senyawasenyawa flavonoid merupakan senyawa alami. Lebih dari 4.000 flavonoid telah diidentifikasi dan dikelompokkan sesuai dengan struktur molekulnya. Salah satu sifat yang dapat menggambarkan flavonoid adalah kemampuan flavonoid untuk beraksi sebagai antioksidan. Flavonoid juga dapat mereduksi inflamasi dan penyakit jantung koroner. Senyawa-senyawa ini merupakan zat warna merah, ungu dan biru dan sebagai zat warna kuning yang ditemukan dalam tumbuhtumbuhan (Astati \& Kasmawati, 2017). Penelitian terdahulu yang dilakukan tentang buah Okra mengatakan bahwa buah Okra memiliki kandungan fenol dan flavonoid yang memiliki efek anti diabetik (Astati \& Kasmawati, 2017). Selain itu penelitian terdahulu juga mengatakan bahwa buah Okra memiliki efek pencegah pada penyakit kronis karena memiliki kandungan flavonoid yang tinggi. Myricetin pada flavonoid dari buah Okra juga menunjukan efek perlindungan pada diabetes terkait nefropati, glaukoma dan katarak (Prabhune et al., 2017).

Penelitian-penelitian terdahulu tentang buah Okra perlu didukung dengan uji kualitatif dan kuantitatif terhadap metabolit sekunder yang terkandung didalamnya. Dengan demikian, dapat memberikan informasi mengenai potensi metabolit sekunder buah Okra sehingga dapat memberikan kontribusi pada peningkatan pemanfaatan sumber daya alam, khususnya dalam bidang farmasi.

\section{METODE PENELITIAN}

\section{Bahan dan Peralatan}

Bahan yang digunakan meliputi Buah Okra (Abelmoschus Esculentus L. Moench) yang diperoleh dari Desa Ganti Kecamatan Banawa Kabupaten Donggala, aluminium foil, aqua Destillata, aqua pro-injeksi, asam klorida, besi(III)klorida, citrate-buffer saline (natrium sitrat, asam Sitrat), Dragendorff LP, handskun, kapas, kertas label, kertas saring, LiebermanBurchard, Na CMC 0,5\%, natrium klorida, serbuk magnesium, tissu, xylol, kuersetin, aquabides, dan metanol.

Alat yang digunakan meliputi ayakan nomor 40 mesh, batang pengaduk blender, cawan porselin, corong kaca, gelas kimia, gelas ukur, inkubator, pipet tetes, rak tabung, rotary vaccum evaporator, stopwatch, tabung reaksi, labu ukur, timbangan analitik, wadah 
maserasi, Waterbath, dan spektrofotometer UV- Vis.

\section{Prosedur Kerja}

\section{Pengambilan dan pengolahan bahan penelitian}

Buah Okra dikumpulkan dan dicuci dengan air mengalir sampai bersih. Selanjutnya dilakukan perajangan kemudian di keringkan dengan cara di angin-anginkan, tanpa terkena sinar matahari langsung hingga bahan tersebut mengering, setelah itu simplisia di haluskan dan diayak.

\section{Pembuatan ekstrak etanol buah Okra}

Pembuatan ekstrak buah Okra dilakukan dengan metode maserasi, yaitu serbuk buah okra yang telah diayak menggunakan ayakan nomor 40 mesh, ditimbang 200 gram lalu diekstraksi secara maserasi dengan menggunakan pelarut etanol $96 \%$ sebanyak 2 liter dan diamkan selama 24 jam sambil sesekali diaduk selama 3 hari. Ekstrak kemudian disaring menggunakan kertas saring lalu diperoleh filtrat. Kemudian filtrat I dan II digabungkan. Selanjutnya dievaporasi atau memisahkan larutan menggunakan Rotary Vaccum Evaporator pada suhu $60^{\circ} \mathrm{C}$ dan dilanjutkan dengan pengentalan yang dilakukan dengan menggunakan waterbath dengan suhu $60^{\circ} \mathrm{C}$ hingga diperoleh ekstrak kental (Tandi, 2017).

\section{Analisis secara kualitatif dan kuantitatif}

Analisis kualitatif kandungan kimia buah Okra, meliputi uji flavonoid, alkaloid, saponin dan tannin (Ergina et al., 2014; Septyaningsih, 2010). Pada uji alkaloid digunakan reagen Dragendroff, uji flavonoid digunakan pereaksi $\mathrm{HCl}$ dan magnesium, uji saponin dilakukan dengan dikocok dalam $\mathrm{HCl} 2 \mathrm{~N}$, dan uji tannin digunakan pereaksi $\mathrm{FeCl}_{3}$. Setelah itu, dilakukan analisis kuantitatif untuk penentuan kadar total senyawa metabolit sekunder (alkaloid, flavonoid, saponin, dan tanin) yang terkandung dalam ekstrak etanol buah Okra menggunakan Spektrofotometer UV-Vis.

\section{HASIL DAN PEMBAHASAN}

Analisis kualitatif senyawa metabolit sekunder (alkaloid, flavonoid, saponin, dan tanin) dilakukan terlebih dahulu pada ekstrak kental buah Okra (Abelmoschus Esculentus L. Moench) berupa uji penapisan fitokimia. Pengujian ini bertujuan untuk mengetahui ada tidaknya senyawa metabolit sekunder (alkaloid, flavonoid, saponin, dan tanin) yang terkandung pada ekstrak etanol buah Okra. Sementara itu, analisis kuantitatif bertujuan untuk mengetahui kadar total senyawa metabolit sekunder (alkaloid, flavonoid, saponin, dan tanin) yang terkandung dalam ekstrak etanol buah Okra dengan menggunakan metode Spektrofotometri UVVis (Behera et al., 2012).

Hasil uji kualitatif pada ekstrak etanol buah Okra diperoleh hasil positif mengandung alkaloid pada uji Dragendorff (Tabel 1) yang ditandai dengan terbentuknya endapan kalium alkaloid (Gambar 1). Pereaksi Dragendorff dibuat dari hasi pencampuran bismut nitrat dengan $\mathrm{HCl}$. Tujuan utama pencampuran tersebut adalah agar ion $\mathrm{Bi}^{3+}$ tetap berada dalam larutan, sehingga kesetimbangan akan bergeser ke arah kiri. Ion $\mathrm{Bi}^{3+}$ bereaksi dengan kalium iodida dan terbentuk endapan hitam bismut (III) iodida yang selanjutnya terlarut dalam kalium iodida dan membentuk kalium tetraiodobismutat. Penggunaan nitrogen pada uji alkaloid dengan Dragendorff ditujukan untuk membentuk ikatan kovalen koordinat dengan ion logam $\mathrm{K}^{+}$(Ergina et al., 2014). 


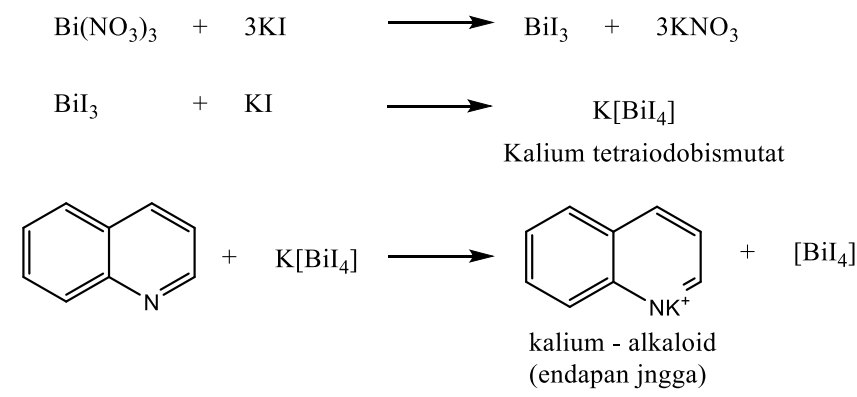

Gambar 1. Reaksi uji Dragendorff (Ergina et al., 2014)

Tabel 1. Hasil penapisan fitokimia (analisis kualitatif) ekstrak etanol buah Okra.

\begin{tabular}{cccc}
\hline Pengujian & Pereaksi & Pengamatan & Hasil \\
\hline Uji Alkaloid & Dragendorff LP & Terbentuk endapan & Positif $(+)$ \\
Uji Flavonoid & $\mathrm{HCl}$ pekat + Magnesium & Terbentuk endapan warna kuning & Positif $(+)$ \\
Uji Saponin & $\mathrm{HCL} 2 \mathrm{~N}$ & Terbentuk buih & Positif $(+)$ \\
Uji Tanin & $\mathrm{FeCl}_{3}$ & Terbentuk warna biru kehitaman & Positif $(+)$ \\
\hline
\end{tabular}

Keterangan: ( + ) Mengandung senyawa yang diuji

Tabel 2. Hasil penetapan kadar (analisis kuantitatif) ekstrak etanol etanol buah Okra

\begin{tabular}{ccc}
\hline No. & Parameter Uji & Kadar $(\mathrm{mg} / \mathrm{gram})$ \\
\hline 1. & Total Alkaloid ekuivalen kuinin & 2168,96 \\
2. & Total Flavonoid ekuivalen kuercetin & 2,79 \\
3. & Saponin berdasarkan standar Quillaja Bark & 10,17 \\
4. & Tanin total ekuivalen asam tanat & 1975,78 \\
\hline
\end{tabular}

Hasil penetapan uji kuantitatif kadar total alkaloid ekuivalen kuinin diperoleh persamaan regresi $y=0,000215332 x-0,000210680 ; R^{2}=$ 0,993. Berdasarkan persamaan regresi tersebut, dilakukan perhitungan kadar total alkaloid ekuivalen kuinin pada sampel sehingga diperoleh kadar total alkaloid ekuivalen kuinin untuk ekstrak etanol buah Okra adalah 2168,72 mg/gram (Tabel 2).

Alkaloid bekerja dengan menstimulasi hipotalamus untuk dapat meningkatkan sekresi Growth Hormone Releasing Hormone $(G H R H)$, sehingga sekresi pada Growth Hormone (GH) dapat meningkat dengan baik. Kadar Growth Hormone (GH) yang tinggi akan menstimulasi hasil untuk mensekresikan Insulin-like Growth Factor-1 (IGF-1). IGF-1 dapat berefek menginduksi pada kondisi hipoglikemia dan menurunkan glukoneogenesis sehingga kadar glukosa dalam tubuh dan kebutuhan insulin menurun (Tandi, 2017). Dalam dunia medis dan kimia organik, istilah alkaloid telah lama menjadi bagian penting dan tak terpisahkan dalam penelitian yang telah dilakukan selama ini, baik untuk mencari senyawa alkaloid baru ataupun untuk penelusuran bioaktifitas.

Hasil uji kualitatif metabolit sekunder flavonoid terhadap ekstrak etanol buah Okra dengan menggunakan pereaksi $\mathrm{HCl}$ dan logam $\mathrm{Mg}$ diperoleh hasil positif mengandung flavonoid (Tabel 1) yang ditandai dengan terbentuknya larutan berwarna kuning (Gambar 2). Tujuan penambahan logam Mg 
dan $\mathrm{HCl}$ untuk mereduksi inti benzopiron yang terdapat dalam struktur flavonoid sehingga terbentuk garam flavilium.

Hasil penetapan uji kuantitatif kadar total flavonoid ekuivalen kuersetin menggunakan kuersetin sebagai kurva baku standar, diperoleh pesamaan regresi yaitu $y=0,00463704 x+0,00215730 ; R^{2}=0,999$. Berdasarkan pesamaan regresi tersebut, dilakukan perhitungan kadar total flavonoid ekuivalen kuersetin pada sampel, diperoleh kadar total flavonoid ekuivalen kuersetin untuk ekstrak etanol buah Okra adalah 2,79 $\mathrm{mg} / \mathrm{gram}$ (Table 2).

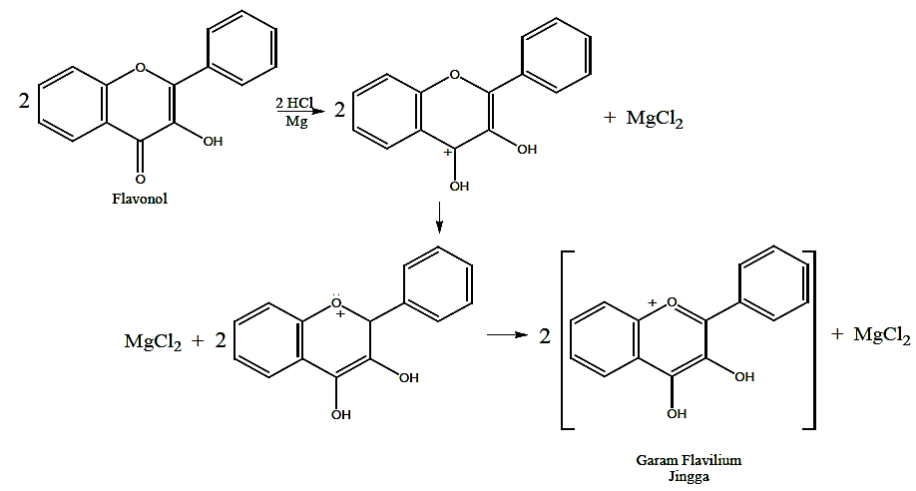

Gambar 2. Reaksi flavonoid dengan $\mathrm{HCl}$ dan logam Mg (Septyaningsih, 2010)

Manfaat utama flavonoid dalam tubuh manusia adalah sebagai antioksidan, antibakteri, dan anti inflamasi. Flavonoid mampu bertindak sebagai antioksidan dan berfungsi menetralisir radikal bebas dan dengan demikian meminimalkan efek kerusakan pada sel dan jaringan tubuh. Dalam mekanisme penyembuhan diabetes melitus, flavonoid diasumsikan memiliki peran secara signifikan untuk meningkatkan aktivitas enzim antioksidan dan mampu meregenerasi sel-sel beta pankreas yang rusak sehingga defisiensi insulin dapat diatasi (Abdelmoaty et al., 2010). Flavonoid khususnya kuercetin, telah dilaporkan memiliki aktivitas antidiabetik (Fitriani et al., 2014). Kuersetin bekerja melalui penghambatan $\alpha$-glukosidase dengan cara menghambat transport glukosa dan fruktosa pada transporter GLUT 2. Penghambatan GLUT 2 menyebabkan pengurangan penyerapan glukosa di lumen usus halus sehingga akan menurunkan kadar glukosa darah (Song et al., 2002).
Hasil uji kualitatif ekstrak etanol buah Okra positif mengandung saponin (Tabel 1) yang ditandai terbentuknya buih pada saat sampel ditambahkan $\mathrm{HCl}$ lalu dikocok, hal ini dikarenakan seyawa saponin memiliki gugus hidrofil yang berikatan dengan air sedangkan gugus hidrofob akan berikatan dengan udara. Penambahan $\mathrm{HCl} 2 \mathrm{~N}$ bertujuan untuk menambah kepolaran sehingga gugus hidrofil akan berikatan lebih stabil dan buih yang terbentuk menjadi stabil.

Hasil penetapan uji kuantitatif kadar saponin terhadap ekstrak etanol buah Okra, diperoleh persamaan regresi yaitu $y=0,000193011 x-0,0039565 ; \quad R^{2}=0,992$. Persamaan regresi tersebut digunakan untuk menghitung kadar saponin pada sampel berdasarkan standar saponin dari Quillaja Bark dan diperoleh kadar saponin kuantitatif adalah 10,17 mg/gram.

Saponin bekerja dengan cara menghambat kenaikan permeabilitas vaskular sehingga mencegah terjadinya inflamasi pada 
sel ginjal dan saponin menghambat superperoksida melalui pembentukan intermediate hidroperoksida, sehingga mencegah kerusakan biomolekul oleh radikal bebas. Saponin dapat memperbaiki fungsi ginjal dengan menurunkan kadar ureum dan kreatinin dengan peningkatan ekskresi ureum dan kreatinin pada urin. Mekanisme kerja saponin dalam menurunkan kadar glukosa darah adalah dengan cara menghambat transport glukosa di dalam saluran cerna dan merangsang sekresi insulin pada sel beta pankreas (Andrie et al., 2014).

Hasil uji kualitatif ekstrak etanol buah Okra, positif mengandung tanin (Tabel 1) yang

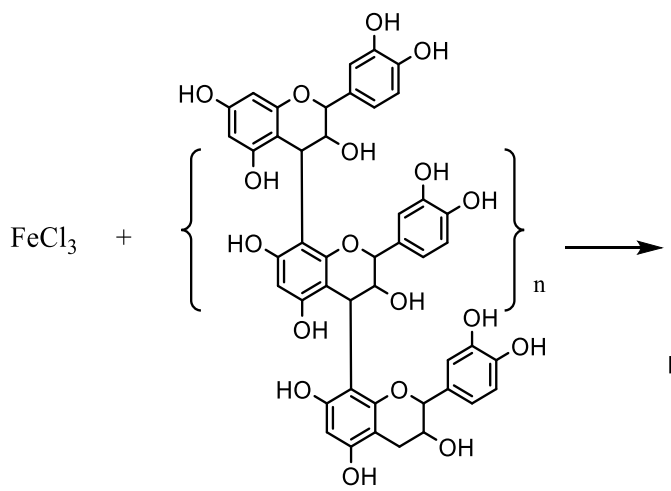

ditandai dengan larutan berwarna hitam setelah ditambahkan larutan $\mathrm{FeCl}_{3}$ (Gambar 3). Hal ini dikarenakan terdapat senyawa fenol dalam tanin yang membentuk senyawa kompleks dengan ion $\mathrm{Fe}^{3+}$.

Hasil penetapan uji kuantitatif kadar tanin total ekuivalen asam tanat diperoleh persamaan regresi senyawa saponin, yaitu $y=$ $0,0423 x+0,0033 ; R^{2}=0,999$. Berdasarkan persamaan regresi tersebut, dilakukan perhitungan kadar tanin total ekuivalenasam tanat pada sampel, sehingga diperoleh kadar untuk ekstrak etanol buah Okra (Abelmoschus Esculentus L. Moench) adalah 1975,78 mg/gram (Tabel 2).

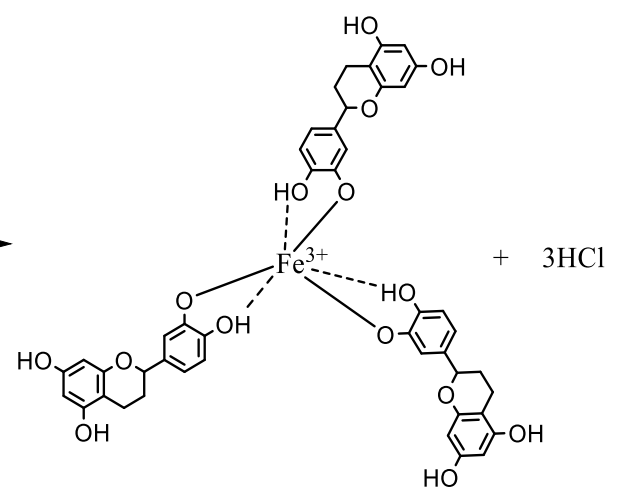

Gambar 3. Reaksi antara tanin dan $\mathrm{FeCl}_{3}$ (Li et al., 2016; Nurzaman et al., 2018)

Tanin diketahui dapat memacu metabolisme glukosa dan lemak sehingga timbunan kedua sumber kalori ini dalam darah dapat dihindari. Tanin mempunyai aktivitas antioksidan dan menghambat pertumbuhan tumor. Tanin juga mempunyai aktivitas hipoglikemik yaitu dengan meningkatkan glikogenesis. Selain itu, tanin juga berfungsi sebagai astringent atau pengkelat yang dapat mengerutkan membran epitel usus halus sehingga mengurangi penyerapan sari makanan dan sebagai akibatnya menghambat asupan gula dan laju peningkatan gula darah tidak terlalu tinggi (Tandi et al., 2018).

\section{KESIMPULAN}

Ekstrak etanol buah Okra (Abelmoschus Esculentus L. Moench) mengandung jenis senyawa metabolit sekunder alkaloid, flavonoid, saponin, dan tanin. Kadar total alkaloid ekuivalen kuinin sebesar 2168,72 mg/gram, kadar total flavonoid ekuivalen kuersetin sebesar 2,79 mg/gram, kadar total saponin berdasarkan standar Quillaja Bark sebesar 10,17 mg/gram, dan kadar total tanin ekuivalen asam tanat sebesar 1975,78 $\mathrm{mg} / \mathrm{gram}$. 


\section{DAFTAR PUSTAKA}

Abdelmoaty, M., Ibrahim, M., Ahmed, N., \& Abdelaziz, M. (2010). Confirmatory studies on the antioxidant and antidiabetic effect of quercetin in rats. Indian Journal of Clinical Biochemistry: IJCB, 25(2): 188-192. https://doi.org/10.1007/s12291010-0034-x

Andrie, M., Taurina, W., \& Ayunda, R. (2014). Activities Test of "Jamu Gendong Kunyit Asam" (Curcuma domestica Val .; Tamarindus indica L.) as an Antidiabetic in Streptozotocin-Induced Rats. Majalah Obat Tradisional, 19(2): 95-102. https://doi.org/10.22146/tradmedj.8147

Astati, \& Kasmawati. (2017). Pengaruh Tepung Okra Terhadap Berat Badan Tikus Wistar Diabetes. Jurnal Sains Dan Teknologi Pangan (JSTP), 2(1): 335-341.

Behera, S., Ganthy, S., Ahmad, F., Santra, S., \& Banerjee, S. (2012). Uv-Visible Spectrophotometric Method Development and Validation of Assay of Paracetamol Tablet Formulation. Journal of Analytical \& Bioanalytical Techniques, 3(6). https://doi.org/10.4172/2155-

9872.1000151

Ergina, Nuryanti, S., \& Pursitasari, I. (2014). Uji Kualitatif Senyawa Metabolit Sekunder pada Daun Palado (Agave angustifolia) yang DiEkstraksi dengan Pelarut Air dan Etanol. Jurnal Akademika Kimia, 3(3): 165-172.

Fitriani, N. E., Ali Akhmad, S., \& Lestariyana, W. (2014). Efek Kuersetin Terhadap Kadar Glukosa Darah Puasa pada Tikus Diabetes Melitus Tipe 2 yang Diinduksi dengan Streptozotocin- Nicotinamide. Jurnal kedokteran dan kesehatan Indonesia, 6(2): 103-110. https://doi.org/10.20885/JKKI.Vol6.Iss2.Art7

Li, Y. M., Miao, X., Wei, Z. G., Cui, J., Li, S. Y., Han, R. M., Zhang, Y., \& Wei, W. (2016). Iron-Tannic Acid Nanocomplexes: Facile Synthesis and Application for Removal of Methylene Blue from Aqueous Solution. Digest Journal of Nanomaterials and Biostructures, 11(4): 1045-1061.
Nurzaman, M., Abadi, S. A., Setiawati, T., \& Mutaqin, A. Z. (2018). Characterization of the phytochemical and chlorophyll content as well as the morphology and anatomy of the Rhizophoraceae family in the mangrove forest in Bulaksetra, Pangandaran. AIP Conference Proceedings, 2021: 030015-1 - 030015-7. https://doi.org/10.1063/1.5062739

Prabhune, A., Sharma, M., \& Ojha, B. (2017). Abelmoschus esculentus (Okra) Potential Natural Compound for Prevention and Management of Diabetes and Diabetic Induced Hyperglycemia: Review. International Journal of Herbal Medicine, 5(2): 65-68.

Septyaningsih, D. (2010). Isolasi dan Identifikasi Komponen Utama Ekstrak Biji Buah Merah (Pandanus conoideus Lamk.). [Skripsi], Universitas Sebelas Maret, Surakarta.

Song, J., Kwon, O., Chen, S., Daruwala, R., Eck, P., Park, J. B., \& Levine, M. (2002). Flavonoid Inhibition of Sodium-dependent Vitamin C Transporter 1 (SVCT1) and Glucose Transporter Isoform 2 (GLUT2), Intestinal Transporters for Vitamin $\mathrm{C}$ and Glucose. Journal of Biological Chemistry, 277(18): 15252-15260. https://doi.org/10.1074/jbc.M110496200

Tandi, J. (2017). Effect of Ethanol Extract Gendola Leaf Leaf (Basella alba L.) on Decreasing Blood Glucose Condition and Histopatology Pankreas White Rats (Rattus norvegicus) Indicated Streptozotocin. JIMR - Journal of Islamic Medicine Research, 1(2): 15-25.

Tandi, J. (2018). Analisis daun gedi merah ( Abelmoschus manihot (L) Medik). EGC, Jakarta.

Tandi, J., Rahmawati, R., Isminarti, R., \& Lapangoyu, J. (2018). Efek Ekstrak Biji Labu Kuning Terhadap Glukosa, Kolesteroldan Gambaran Histopatologi Pankreas Tikus HiperkolesterolemiaDiabetes. Talenta Conference Series: Tropical Medicine (TM), 1(3): 144-151. https://doi.org/10.32734/tm.v1i3.280 